\title{
Review
}

\section{Dietary Factors Modulating Colorectal Carcinogenesis}

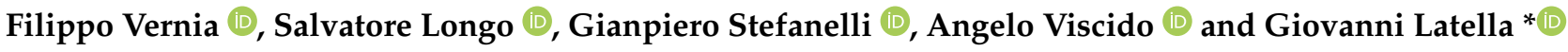 \\ Department of Life, Health, and Environmental Sciences, Division of Gastroenterology, Hepatology, and \\ Nutrition, University of L'Aquila, Piazza S. Tommasi, 1- Coppito, 67100 L'Aquila, Italy; \\ filippo.vernia1@gmail.com (F.V.); salvator.longo@gmail.com (S.L.); giastefanelli@gmail.com (G.S.); \\ angelo.viscido@univaq.it (A.V.) \\ * Correspondence: giolatel@tin.it; Tel.: +39-0862-434-735; Fax: +39-0862-433-425
}

\begin{abstract}
The development of colorectal cancer, responsible for $9 \%$ of cancer-related deaths, is favored by a combination of genetic and environmental factors. The modification of diet and lifestyle may modify the risk of colorectal cancer (CRC) and prevent neoplasia in up to $50 \%$ of cases. The Western diet, characterized by a high intake of fat, red meat and processed meat has emerged as an important contributor. Conversely, a high intake of dietary fiber partially counteracts the unfavorable effects of meat through multiple mechanisms, including reduced intestinal transit time and dilution of carcinogenic compounds. Providing antioxidants (e.g., vitamins $C$ and E) and leading to increased intraluminal production of protective fermentation products, like butyrate, represent other beneficial and useful effects of a fiber-rich diet. Protective effects on the risk of developing colorectal cancer have been also advocated for some specific micronutrients like vitamin D, selenium, and calcium. Diet-induced modifications of the gut microbiota modulate colonic epithelial cell homeostasis and carcinogenesis. This can have, under different conditions, opposite effects on the risk of CRC, through the production of mutagenic and carcinogenic agents or, conversely, of protective compounds. The aim of this review is to summarize the most recent evidence on the role of diet as a potential risk factor for the development of colorectal malignancies, as well as providing possible prevention dietary strategies.
\end{abstract}

Keywords: colorectal cancer; diet; nutrition; red meat; processed meat; fiber; vitamins; short chain fatty acids (SCFA)

Stefanelli, G.; Viscido, A.; Latella, G Dietary Factors Modulating Colorectal Carcinogenesis. Nutrients 2021, 13, 143. https://doi.org/ $10.3390 /$ nul13010143

Received: 5 December 2020 Accepted: 29 December 2020 Published: 3 January 2021

Publisher's Note: MDPI stays neutral with regard to jurisdictional clai$\mathrm{ms}$ in published maps and institutional affiliations.

Copyright: (C) 2021 by the authors. Licensee MDPI, Basel, Switzerland. This article is an open access article distributed under the terms and conditions of the Creative Commons Attribution (CC BY) license (https:// creativecommons.org/licenses/by/ $4.0 /)$.

\section{Introduction}

Colorectal cancer (CRC) is a highly common malignancy, being the third leading cause of cancer death worldwide. It has been estimated that in 2018 the incidence of new cases has been approximately 2 million, determining 1 million deaths worldwide [1].

CRC is a silent disease, often presenting in advanced form, developing as a slow, multi-step process, that takes approximately 5-10 years from premalignant lesions to CRC [2].

Moreover, being influenced by several risk factors related to the patient (including age, sex, and familial predisposition) and environment (diet, excess body weight, and tobacco use), CRC may be modulated by targeted risk reduction measures [3].

Although in the past years the carcinogenic effect of diet was mainly attributed to highfat, high-calorie diets, an increasing amount of attention is now focused on the specific role of different nutrients like fibers, vitamins, and minerals, as well as of intestinal microbiome metabolism.

Indeed, the World Cancer Research Fund/American Institute of Cancer Research (WCRF/AICR), suggests that CRC could be prevented in up to $50 \%$ of cases, modifying risk factors such as diet and lifestyle behaviors [4]. The same report states that consuming whole grains, dietary fiber, and dairy products decreases the risk of CRC. Conversely, the Western diet, characterized by a high intake of red and processed meat (rich in heme iron) and fat increases the risk of CRC. Some evidence supports the protective effect of vitamin C, fish, and vitamin D, in decreasing the risk of CRC [4]. 
Thus, dietary intervention has emerged in the last decades as an attractive strategy to reduce the occurrence and progression of CRC.

The aim of this narrative review is to summarize the most recent evidence on the role of diet as a potential risk factor for the development of colorectal malignancies, as well as providing dietary strategies that may counteract this effect.

\section{Materials and Methods}

A systematic electronic search of the English literature up to November 2020 was performed using Medline, Excerpta Medica database (EMBASE), Web of Science, Scopus, and the Cochrane Library. The search strategy used a combination of Medical Subject Headings (MeSH) and keywords as follows: "colorectal cancer", "CRC", "colorectal adenoma", "risk factors", "carcinogens", "diet", "dietary habit", "food", "meat", "red meat", "processed meat", "heme iron", "proteins", "fat", "lipids", “carbohydrates", "sugar", "refined sugars", "nitrates", "nitrites", "nitrosamines" "dietary fibers", "vegetables", "fruit", "dietary minerals", "calcium", "selenium", "nutrients", "vitamins", "vitamin C", "vitamin D", vitamin E", "antioxidants", "gut microbiota", "fecal organic anions", "fecal short-chain fatty acids", "short chain fatty acids", "SCFA", "butyrate".

Three authors (Filippo Vernia, Salvatore Longo, and Gianpiero Stefanelli) identified relevant articles by screening the abstracts. Additional studies were selected after a manual review of the reference list of the identified studies and review articles. Any discrepancy was resolved by consensus, referring to the original articles. Out of 4573 citations, 118 relevant articles were selected and included in the present narrative review.

\section{Red and Processed Meat and Colorectal Cancer}

Processed meat, defined as meat that has been transformed through salting, curing, fermentation, smoking, or other processes to enhance flavor or improve preservation, and red meat have been included in 2015 in the list of substances that can contribute to the development of cancer, by the International Agency for Research on Cancer (IARC). Based on available data, the study group concluded that processed meat is carcinogenic (Group 1), while red meat is probably carcinogenic (Group 2A) [4].

Therefore, it has been recommended that the intake of red meat is limited to less than three portions weekly, corresponding to 350-500 g (12-18 oz) of cooked weight [4]. Processed meat, more so smoked and nitrite-containing foods, should be avoided, as no level of intake can confidently be associated with a lack of risk [4].

The association between CRC and enhanced consumption of red and processed meat, leading to this recommendation, is supported by considerable evidence.

The European Prospective Investigation into Cancer and Nutrition (EPIC) provided strong evidence of this association in more than 500,000 individuals [5] as habitual meat consumers had a $20 \%$ higher risk to develop CRC, compared to non-consumers or occasional consumers [5].

Similarly, the Norwegian Women and Cancer (NOWAC) cohort, including 88,000 women, concluded that consuming more than $60 \mathrm{~g}$ processed meat a day doubles the risk of developing CRC compared to less than $15 \mathrm{~g}$ [6].

Other cohorts reported that the daily ingestion of $100 \mathrm{~g}$ of fresh red meat determines a $17 \%$ increased risk of CRC, while $50 \mathrm{~g}$ processed red meat raises the risk by $18 \%$ [4].

In contrast, there is not enough evidence to support the role of white meat consumption in increasing the risk of CRC.

The carcinogenic effects of red and processed meat are mainly related to the presence of growth-promoting dietary components, such as heme and arginine, enhanced mutagenic intestinal environment, and intestinal inflammatory response [7].

The best-studied mechanism involves heme iron [8], converted in the colon into cytotoxic heme factor (CHF). This damages the surface epithelial cells [9] and induces reactive epithelial hyperproliferation. The abundance of mucin-degrading bacteria, such as Akkermansia muciniphila, and sulfate-reducing bacteria enhances these effects [9]. 
Colonic damage is boosted by the production of reactive oxygen species (ROS) induced by heme iron, which favors the oxidation of DNA, lipids, and proteins [10].

Heme has been shown in animal models to inhibit colonocyte apoptosis and exfoliation, providing an additional mechanism contributing to carcinogenesis [11].

Heme iron increases the production of N-nitroso compounds (NOCs) [12]. Nitrosamines, synthesized by the intestinal microbiota from the nitrites, are particularly active carcinogenic compounds [13]. Processed meat is still often supplemented with nitrites to favor preservation. Free nitrosyl heme has been shown in animal models to synthesize more NOCs during cooking than native heme [14]. Moreover, hemoglobin and myoglobin directly react with nitrites, forming N-nitroso-hemoglobin and N-nitrosomyoglobin, possibly explaining the dose-dependent effect of red meat [15].

Additionally, arginine, as a precursor of polyamines, has been proposed as a potential CRC risk factor [16]. Polyamines, such as putrescin, spermidine, and spermine, are involved in cellular processes, including proliferation, and provide an additional mechanism linking red meat to CRC $[7,17]$.

Several genotoxic and mutagenic substances particularly NOCs and oxidized lipids result from preservation, curing, and/or cooking process and bacterial metabolic activity $[7,18]$. Heterocyclic amines (HCAs) formed upon over-heating amino acids and sugars, either alone or in association with polycyclic aromatic hydrocarbons (PAHs), and nitrites/nitrates, are also harmful [7].

An additional mechanism contributing to CRC is lipidic peroxidation [7]. This results in the production of O6-carboxymethyl guanine adducts and other molecules with toxic and mutagenic effects [19]. Interestingly, lipidic peroxidation is further enhanced by heme iron [20], in relation to the catalytic activity on the bacterial production of aldehydes, which in turn increases the genotoxic effect [21].

Some evidence supports the potentially harmful effect of other protein fermentation products. Hydrogen sulfide promotes both inflammation and the proliferation of CRC cells [22,23], 4-hydroxyphenyl-acetic acid is genotoxic, and phenylacetic acid and phenol exert cytotoxic effects [24].

\section{High-Fat Diet, Biliary Acids, and Colorectal Cancer}

Recent data further support the tumor-promoting activity of high-fat diets, largely depending on the complex interactions between the gut microbiota and bile acid metabolism [25,26].

Excess dietary fat stimulates the hepatic synthesis of bile acids, resulting in increased amounts of bile acids escaping the ileal reabsorption by apical sodium-dependent bile acid transporter or the ileal bile acid transporter. As a consequence of their deconjugation by microbial enzymes, the ratio of primary to secondary bile acids entering enterohepatic cycling and within the colonic lumen is modified [26].

Recent data support the well-known concept that lower levels of bile acids and $7 \alpha$ dehydroxylating bacteria are present in the stool of healthy rural Africans than in those of healthy African Americans. The latter group consuming a high-fat, low-fiber diet has a much high prevalence of CRC, compared to the former one, consuming a low-fat, high-fiber diet [27]. Interestingly, a diet switch leads to lower fecal levels of bile acids and $7 \alpha$-dehydroxylating bacteria in African Americans, while the opposite is true for rural Africans, in parallel to an increase of mucosal markers associated with CRC risk [28].

Despite several studies aiming to clarify the tumor-promoting function of bile acids, including oxidative stress and inflammation, the underlying molecular mechanisms remain unclear. Multiple mechanisms stimulating CRC cell proliferation have been advocated for secondary bile acids, including receptor-dependent signaling pathways [29], the activation of $\beta$-catenin cell-signaling, extracellular signal-regulated kinases 1 and 2 (ERK1/2), signaling via activator protein 1 (AP1) and c-Myelocytomatosis (c-Myc) target pathways [30,31]. An additional CRC pathway activated by secondary bile acids is the nuclear factor kappa $\mathrm{B}(\mathrm{NF}-\mathrm{kB})$ pathway [32]. 
Recently, the role of farnesoid X receptor (FXR) signaling in gut-liver crosstalk has been identified as central in the control of intestinal epithelial cell proliferation. FXR deficiency promotes the proliferation of colonic epithelial cells accompanied by a high expression of cyclin D1 [33] in keeping with the reduced expression of FXR in precancerous lesions and CRC [34]. Animal studies show that a high-fat diet induces an altered activity of FXR, correlating with higher numbers of Ki-67+ cells in colonic crypts [35]. The cell cycle antigen $\mathrm{Ki}-67$ is a nuclear protein associated with cellular proliferation.

\section{Fibers and Colorectal Cancer}

The observation that the prevalence of CRC increases inversely to the intake of dietary fiber led in the last decades to extensive investigation on the protective role of fibers, especially whole grain $[4,36]$. Similarly, the European Prospective Investigation into Cancer and Nutrition (EPIC) study documented a $40 \%$ reduction in CRC risk in the highest quintile of fiber intake compared with the lowest [5].

This has also been recently confirmed by an update of the National Institutes of Health and American Association of Retired Persons (NIH-AARP) Diet and Health Study [37], following more than 10,000 participants over 15 years. The study confirms that the intake of whole grains, but not dietary fiber from other origins, is inversely associated with CRC risk. Participants in the highest quintile of intake of whole grains had a $16 \%$ lower risk of CRC compared with those in the lowest quintile [37]. This study also strongly suggests that the protective effect depends on the whole grain-containing food, in which other constituents (e.g., folate) are present, more than the fiber content. This important point was previously undefined [38].

The chemoprotective effect of fibers in different colonic segments however seems to vary with food source [39]. Similar partially conflicting conclusions have also been drawn for the inverse association between fibers and adenoma [40,41].

Several mechanisms have been suggested to explain how dietary fiber may reduce CRC, ranging from dilution of carcinogens in larger amounts of stool resulting from the ingestion of non-fermentable fiber, to highly sophisticated intracellular metabolic effects triggered by fermentation by products [36]. The mere reduction of fecal $\mathrm{pH}$ induced by dietary fiber fermentation decreases the production of bacterial carcinogens deriving from bile acid metabolism [42]. Intraluminal acidification reduces intestinal transit time and colonocyte exposure to carcinogens, thus representing an additional chemoprotective effect of dietary fiber [43]. Moreover, it has been reported a higher large bowel intraluminal $\mathrm{pH}$ in patients with CRC compared to healthy controls [44,45], more so when measuring the $\mathrm{pH}$ of the colonic mucosal surface than that of luminal contents [46].

Fiber fermentation by gut microbiota leads to the production of short-chain fatty acids (SCFA), predominantly acetate, butyrate, and propionate, in a ratio of 3:1:1 [47].

Butyrate, besides representing the main energy source in normal colonocytes, shows a protective effect on colonic mucosa [48]. Butyrate has anti-inflammatory properties, as it has been reported a reduction of plasmatic pro-inflammatory cytokines and an increment of regulatory T-lymphocytes in animal models [49].

Butyrate reduces proliferation and increases differentiation of CRC cells [48].

Furthermore, it has been also reported that butyrate induces apoptosis in CRC cells [50], acting as a potent histone deacetylase inhibitor and through the activation of the Fas receptor-mediated extrinsic death pathway [51].

An additional mechanism by which butyrate may determine a protective effect against $\mathrm{CRC}$ is the induction of colonocyte apoptosis, due to the production of cellular reactive oxygen species (ROS) [52], which determines the release of proapoptotic factors [53].

Of particular interest is the differing behavior of butyrate on normal colonic cell lines and colon cancer cells. In normal cells, it increases cell weight, increases DNA content, and increases proliferation and crypt length, with the energy provided. This is in line with the mucosal anti-inflammatory effect of butyrate reported in ulcerative colitis [54]. 
In cancer cells favors the arrest in the G1 phase and differentiation due to a direct effect on mutated $G$ protein and decreases cloning efficiency and adhesion to laminin [55]. The reduction of cellular proliferation and increase of differentiation of CRC cells has also been described in small in vivo studies [56].

Other putative beneficial mechanisms of butyrate are represented by the modulation of micro-RNAs (miRNAs), small non-coding RNA molecules. High butyrate levels reduce the expression of MYC oncogene, which in turn reduces the levels of the miRNA-17-92 cluster miRNAs, playing a central role in cellular proliferation, metastasis, and angiogenesis [57].

More recently attention has been paid to the differing effects of different fibers (e.g., soluble and insoluble) which modulate the composition of the microbiota and influence the microbial production of butyrate and other intermediate compounds of bacterial metabolism [58].

Despite the vast amount of evidence deriving from epidemiologic, basic science, and animal studies, results in humans are still conflicting and largely inconclusive $[59,60]$.

\section{Vitamins, Minerals, and Colorectal Cancer}

Besides the higher intake of fibers associated with a lower intake of meat, consumption of fruit and vegetables may reduce the incidence of CRC [61] in relation to their content of specific micronutrients, such as vitamins and polyphenols [36].

Vitamin C and E showed a direct tumor-suppressing effect on CRC cell lines [62,63]. A negative association has been also reported in a cohort from Shanghai [64] for vitamin C, and in a Canadian cohort [65] for vitamin E, but not in other studies [66]. The possible protective effect of these vitamins in CRC is thus debated although the removal of free radicals counteracts the production of NOCs from nitrites and nitrates [67].

However, several intervention studies did not provide consistent support for an inverse association between supplemental vitamin $\mathrm{E}$ or C, and CRC $[68,69]$

It has been advocated that vitamin $\mathrm{D}$ also reduces the risk of CRC inhibiting neoangiogenesis and cellular proliferation, and inducing apoptosis [70,71]. A metanalysis published in 2005 highlighted the need to identify the required levels to exert this protective effect [72]. The issue is still unsolved, but very high Vitamin D concentrations are likely required. In a recent prospective trial on 25,871 men, however, vitamin D supplementation did not reduce the incidence of invasive cancer after a 5.3-year follow-up [73]. Therefore, these data seem to limit the effectiveness of this intervention.

An inverse association with CRC has been also reported for selenium and calcium.

The putative effect of selenium is due to its antioxidant and anti-inflammatory properties, and upregulation of the glutathione peroxidase 2 [74].

Despite a meta-analysis [75] reported that selenium supplementation is associated with a reduction in the incidence of $C R C$, recent studies did not confirm the protective effect $[76,77]$.

Similar conclusions may be drawn for calcium intake. An old, pooled analysis from prospective cohorts reported a $22 \%$ reduction in CRC incidence in the highest quintile of dietary calcium intake compared to the lowest quintile [78]. More recent studies did not confirm a protective role of this mineral [79,80], however, the evidence may be considered somewhat stronger than for selenium.

Again, the underlying mechanisms are not clear. Calcium possibly acts indirectly, form soaps that bind secondary bile acids and fatty acids [81], as well as directly, through the reduction of cell proliferation and inducing apoptosis [70,71]. It has also been reported that calcium may also contrast the cytotoxic effect of heme iron on the colonic mucosa [82].

Other putative mechanisms involve modulation of the expression of transforming growth factor-alpha and beta 1 [83] and the expression of the b-catenin gene [84].

Among the most relevant microbial metabolites having a protective effect against CRC, strong evidence is reported on niacin. It suppresses inflammation and tumor progression acting both on macrophages and dendritic cells, as well as promoting differentiation of Treg and IL-10-producing T cells [85]. 


\section{Gut Microbiota and Colorectal Cancer}

The role of gut microbiota in the development of CRC through specific biochemical pathways is becoming increasingly evident $[86,87]$. Microbes produce toxic metabolites or carcinogenic products [88]. Moreover, other products of bacterial metabolism may exert an indirect effect, as lactate that represents the prevalent energy source in CRC cells $[89,90]$.

Similarly, bacterial toxins such as the enterotoxigenic one produced by Bacteroides fragilis play a central role in CRC development through several mechanisms such as the activation of $\beta$-catenin signaling, the cleavage of E-cadherin, and the induction of NF- $\mathrm{kB}$ pathway [91]. Similar pathways are also activated by Fusobacterium nucleatum and Escherichia coli $[92,93]$.

However, the relationship between noxious bacterial species and CRC is probably bidirectional, as it has been recently reported that after CRC treatment the gut microbiota changes, becoming more similar to that of patients with a normal colon [94].

Conversely, as previously mentioned, some bacterial metabolites such as SCFA or niacin have protective effects against CRC. Nonetheless, the specific role of most microbial metabolites remains unclear or displays differing effects in different conditions. Succinate, for example, has been shown to inhibit CRC cell proliferation in some studies [95], while others suggest that succinate can promote metastasis [96].

Further complicating the interplay between host and microbiota, most bacterial metabolites are not produced by individual species. End-metabolic compounds deriving from the metabolism of some bacteria, represent intermediate metabolites for others. For example, butyrate is produced by several bacteria distributed across four different phyla: Firmicutes, Fusobacteria, Spirochaetes, and Bacteroidetes [97]. At the same time Roseburia spp. can use acetate, produced by other bacteria, for synthesizing butyrate [98], while methanogenic Archaea and sulfide-producing bacteria instead reduce or further metabolize butyrate in the colon [99]. These interactions show how the production of microbial metabolites by helpful/harmful species may not correspond to the concentration acting on the colonic mucosa, limiting our knowledge on the doses of each bacterial compound needed to have a beneficial/detrimental effect.

Diet may thus affect CRC risk directly providing helpful or noxious substances, modifying the intraluminal media, influencing and modulating the abundance and type of microbial community as well as increasing or reducing the production of specific metabolites [100]. To further confound the issue, this complex interaction is further modulated by specific metabolic characteristics and microbial communities that are different across individuals [101].

Despite the evidence is still conflicting [102,103], recent studies, suggest a possible positive immunomodulatory effect, as well as an improvement of the gut-barrier activity induced by several probiotics $[104,105]$.

Further studies are therefore needed to clarify whether specific nutrients exert their protective or damaging effect directly on the colorectal epithelium or indirectly by inducing changes in the metabolism of the microbiome (Figure 1).

The rapidly increasing knowledge of the complex crosstalk between the host, gut microbiome, and microbial metabolites suggests that tailored dietary intervention might become pivotal in the prevention of several diseases, including CRC. 


\section{PROCARCINOGENETICEFFECTS}

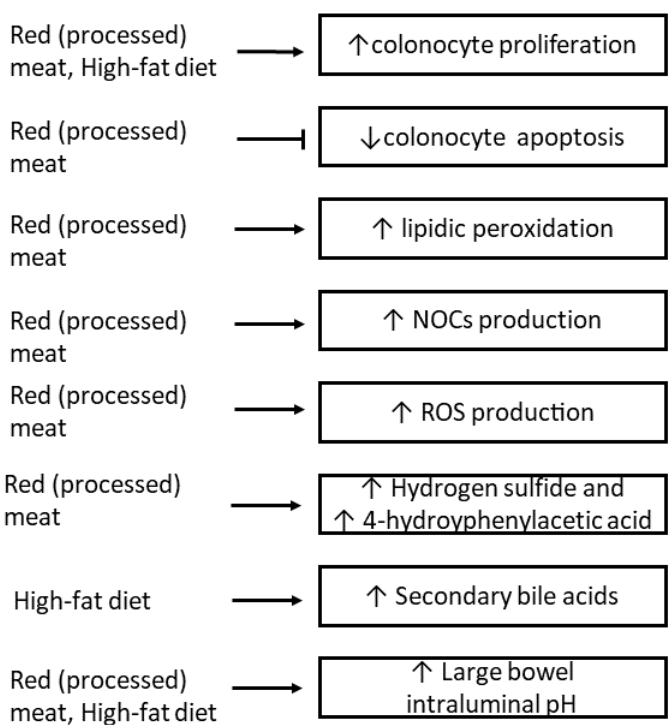

vs

\section{ANTICARCINOGENETIC EFFECTS}

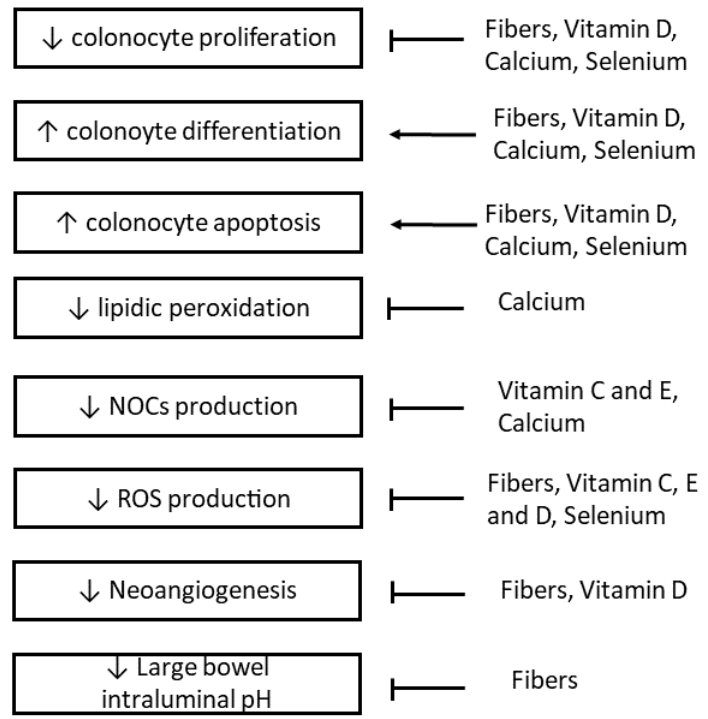

Figure 1. Schematic representation of the mechanisms of specific dietary components in improving or contrasting the carcinogenic processes on large bowel mucosa. $\uparrow$ : increase; $\downarrow$ : reduction.

\section{Nutrients, Epigenetics and Colorectal Cancer}

In the last decade, an increasing amount of attention has been focused on the connection between gene regulation and CRC. Several nutrients affect gene expression, binding transcription factors, or being involved in post-translational modifications, such as acetylation and methylation.

The promotion of intestinal carcinogenesis may be favored by epigenetic modifications triggered by red and processed- meat.

Just one week of a high red meat diet induces the activation of the Nucleosome Remodeling and Deacetylase (NuRD) complex involved in methylation-mediated gene silencing, in human gut biopsy samples [106].

Heme-supplemented diet suppresses Wif1 and BMP2 genes-which antagonize the Wnt signaling cascade and promote differentiation of intestinal cells-in mice [11].

Heme also binds other transcription factors, including Bach1, promoting histone deacetylation, and repressing a subset of $p 53$ target genes, involved in cellular senescence $[107,108]$. Mitotic chromosome alignment during metaphase is also affected by Bach1 [109].

Conversely, the Mediterranean diet exerts a protective effect against CRC mediated by DNA methylation of the human runt-related transcription factor 3 (RUNX3) [110]. The methylation of apoptosis-related genes following the administration of other nutrients like $n-3$ polyunsaturated fatty acids and fibers, directly or mediated by SCFA and other fermentation products, is also protective [111,112].

The same proves true for other dietary components, such as polyphenols [113] vitamins [114-116], and minerals [116,117] alone or in combination.

Dietary bioactive compounds influence epigenetic modification of CRC-related genes, but additional studies are needed to understand the mechanisms of action of putative protective nutrients, as most of the evidence comes from in vitro or animal studies.

Nutritional therapies based on epigenetically active nutrients shall likely represent shortly a fruitful research field.

\section{Conclusions}

The latest WCRF/AICR report assesses that CRC primary prevention mainly consists of a healthy diet and a physically active lifestyle. A strong relationship between diet and the development of CRC is widely accepted (Figure 1). Consumption of whole grains, 
dietary fiber, and dairy products is protective, which is the opposite to the consumption of red and processed meat, and fat-rich diets. Some evidence indicates that consuming foods containing vitamin C, E, and D as well as some minerals (e.g., calcium and selenium) might decrease the risk of CRC [4]. However, studies on incidence and mortality are challenging, due to the sample size and duration of randomized trials required to test the effect of dietary intervention. Moreover, since specific nutrients are not consumed in isolation, but as part of dietary patterns, and dietary components interact with each other, the actual effect of diet on CRC risk may become apparent only when individual components are considered as a whole. Thus, which type of whole diets proves of real benefit is still largely undefined. More so for recommended doses of individual foodstuffs.

Due to the time required for the development of CRC, most hypotheses deriving from in vitro or animal studies, have been tested in humans as polyp prevention trials, in which the colorectal polyps are used as a biomarker of CRC risk. This strategy, however, might not be fully satisfactory.

Despite the complex interplay with the dietary pattern, the microbiome is recognized as central in the development of CRC, but current knowledge is only the tip of the iceberg and dietary recommendations aiming to select or inhibit individual phyla or bacterial strains are presently out of reach.

Epigenetic modifications induced by specific nutrients or microbial metabolites are a new and promising research area that could significantly contribute to unravel the complex colorectal carcinogenetic process.

Current dietary advice is aimed at limiting unhealthy, fat- and protein-rich Western diets, in favor of increased consumption of fruit, vegetables, and cereals, or the so-called Mediterranean diet.

Diet, however, is the expression of complex cultural interactions and is rapidly evolving. There is an important variation in trends of colorectal cancer incidence worldwide which were found to be related to the dietary habits of each country [118]. Nowadays, the so-called Mediterranean diet markedly differs from that of a few decades ago. This is evidenced by the increasingly frequent habit of following a high-calorie, high-fat, almost fibreless diet in most of the urban areas of countries that traditionally followed the Mediterranean diet.

Food is a significant part of the culture of humans and is central to life and well-being. Local dietary habits should always be considered and suggesting just one healthy diet to different populations would likely lead to low adherence and unsatisfactory performance in the prevention of CRC. However, the application of legislative and educational measures promoting a healthy diet has become an urgent issue to stop the increasing tendency of colorectal cancer reported worldwide [118]. Future recommendations shall likely be tailored to individual patients, considering genetic and cultural backgrounds, as well as individual risk factors, the interaction between nutrients and a patient's specific microbiota.

Author Contributions: F.V., S.L., and G.S. performed the literature review, wrote the manuscript, and prepared the Figures; A.V. and G.L. reviewed the manuscript and provided critical comments; G.L. suggested the topic of the review and supervised, wrote, and critically reviewed the manuscript. All authors have read and agreed to the published version of the manuscript.

Funding: No financial support was received for this study.

Conflicts of Interest: The authors have no conflict of interest to declare and did not use any outside assistance in preparing the manuscript.

\section{References}

1. Rawla, P.; Sunkara, T.; Barsouk, A. Epidemiology of colorectal cancer: Incidence, mortality, survival, and risk factors. Prz. Gastroenterol. 2019, 14, 89-103. [CrossRef] [PubMed]

2. Strum, W.B. Colorectal adenomas. N. Engl. J. Med. 2016, 374, 1065-1075. [CrossRef] [PubMed]

3. Keum, N.; Giovannucci, E. Global burden of colorectal cancer: Emerging trends, risk factors and prevention strategies. Nat. Rev. Gastroenterol. Hepatol. 2019, 16, 713-732. [CrossRef] [PubMed] 
4. World Cancer Research Fund; American Institute of Cancer Research. Continuous Update Project Report: Diet, Nutrition, Physical Activity and Colorectal Cancer. 2018. Available online: https://www.wcrf.org/sites/default/files/Colorectal-cancerreport.pdf (accessed on 3 February 2018).

5. Norat, T.; Bingham, S.; Ferrari, P.; Slimani, N.; Jenab, M.; Mazuir, M.; Overvad, K.; Olsen, A.; Tjønneland, A.; Clavel, F.; et al. Meat, fish, and colorectal cancer risk: The European Prospective Investigation into cancer and nutrition. J. Natl. Cancer Inst. 2005, 97, 906-916. [CrossRef] [PubMed]

6. Parr, C.L.; Hjartaker, A.; Lund, E.; Veierod, M.B. Meat intake, cooking methods and risk of proximal colon, distal colon and rectal cancer: The Norwegian Women and Cancer (NOWAC) cohort study. Int. J. Cancer 2013, 133, 1153-1163. [CrossRef]

7. Hammerling, U.; Laurila, J.B.; Grafström, R.; Ilbäck, N.G. Consumption of red/processed meat and colorectal carcinoma: Possible mechanisms underlying the significant association. Crit. Rev. Food Sci. Nutr. 2016, 56, 614-634. [CrossRef]

8. Sasso, A.; Latella, G. Role of heme iron in the association between red meat consumption and colorectal cancer. Nutr. Cancer 2018, 70, 1173-1183. [CrossRef]

9. Ijssennagger, N.; Belzer, C.; Hooiveld, G.J.; Dekker, I.; van Mil, S.W.C.; Michael Müller, M.; Michiel Kleerebezem, M.; Roelof van der Meer, R. Gut microbiota facilitates dietary heme-induced epithelial hyperproliferation by opening the mucus barrier in colon. Proc. Natl. Acad. Sci. USA 2015, 112, 10038-10043. [CrossRef]

10. Liu, H.; Liu, X.; Zhang, C.; Zhu, H.; Xu, Q.; Bu, Y.; Lei, Y. Redox imbalance in the development of colorectal cancer. J. Cancer 2017, 8, 1586-1597. [CrossRef]

11. Ijssennagger, N.; Rijnierse, A.; de Wit, N.; Jonker-Termont, D.; Dekker, J.; Müller, M.; van der Meer, R. Dietary haem stimulates epithelial cell turnover by downregulating feedback inhibitors of proliferation in murine colon. Gut 2012, 61, 1041-1049. [CrossRef]

12. Cross, A.J.; Pollock, J.R.; Bingham, S.A. Heme, not protein or inorganic iron, is responsible for endogenous intestinal N-nitrosation arising from red meat. Cancer Res. 2003, 63, 2358-2360. [PubMed]

13. Calmels, S.; Ohshima, H.; Bartsch, H. Nitrosamine formation by denitrifying and non-denitrifying bacteria: Implication of nitrite reductase and nitrate reductase in nitrosation catalysis. J. Gen. Microbiol. 1988, 134, 221-226. [CrossRef] [PubMed]

14. Pierre, F.H.P.; Santarelli, R.L.; Allam, O.; Tache, S.; Naud, N.; Gueraud, F.; Corpet, D.E. Freeze-dried ham promotes azoxymethaneinduced mucin-depleted foci and aberrant crypt foci in rat colon. Nutr. Cancer 2010, 62, 567-573. [CrossRef]

15. Bonnett, R.; Martin, R.A. Interaction of nitrite with haems and related compounds. IARC Sci. Publ. 1976, 14, 487-493.

16. Zell, J.A.; Ignatenko, N.A.; Yerushalmi, H.F.; Ziogas, A.; Besselsen, D.G.; Gerner, E.W.; Anton-Culver, H. Risk and risk reduction involving arginine intake and meat consumption in colorectal tumorigenesis and survival. Int. J. Cancer 2007, 120, 459-468. [CrossRef] [PubMed]

17. Raj, K.P.; Zell, J.A.; Rock, C.L.; McLaren, C.E.; Zoumas-Morse, C.; Gerner, E.W.; Meyskens, F.L. Role of dietary polyamines in a phase III clinical trial of difluoromethylornithine (DFMO) and sulindac for prevention of sporadic colorectal adenomas. Br. J. Cancer 2013, 108, 512-518. [CrossRef] [PubMed]

18. Gratz, S.W.; Wallace, R.J.; El-Nezami, H.S. Recent perspectives on the relations between fecal mutagenicity, genotoxicity, and diet. Front. Pharmacol. 2011, 2, 4. [CrossRef]

19. Lewin, M.H.; Bailey, N.; Bandaletova, T.; Bowman, R.; Cross, A.J.; Pollock, J.; Shuker, D.E.G.; Bingham, S.A. Red meat enhances the colonic formation of the DNA adduct O6-carboxymethyl guanine: Implications for colorectal cancer risk. Cancer Res. 2006, 66, 1859-1865. [CrossRef]

20. Corpet, D.E. Red meat and colon cancer: Should we become vegetarians, or can we make meat safer? Meat Sci. 2011, 89, 310-316. [CrossRef]

21. Bastide, N.M.; Chenni, F.; Audebert, M.; Santarelli, R.L.; Taché, S.; Naud, N.; Baradat, M.; Jouanin, I.; Surya, R.; Hobbs, D.A.; et al. A central role for heme iron in colon carcinogenesis associated with red meat intake. Cancer Res. 2015, 75, 870-879. [CrossRef]

22. Beaumont, M.; Andriamihaja, M.; Lan, A.; Khodorova, N.; Audebert, M.; Blouin, J.M.; Grauso, M.; Lancha, L.; Benetti, P.H.; Benamouzig, R.; et al. Detrimental effects for colonocytes of an increased exposure to luminal hydrogen sulfide: The adaptive response. Free Radic. Biol. Med. 2016, 93, 155-164. [CrossRef] [PubMed]

23. Sakuma, S.; Minamino, S.; Takase, M.; Ishiyama, Y.; Hosokura, H.; Kohda, T.; Ikeda, Y.; Fujimoto, Y. Hydrogen sulfide donor GYY4137 suppresses proliferation of human colorectal cancer Caco-2 cells by inducing both cell cycle arrest and cell death. Heliyon 2019, 5, 02244. [CrossRef] [PubMed]

24. Armand, L.; Andriamihaja, M.; Gellenoncourt, S.; Bitane, V.; Lan, A.; Blachier, F. In vitro impact of amino acid-derived bacterial metabolites on colonocyte mitochondrial activity, oxidative stress response and DNA integrity. Biochim. Biophys. Acta Gen. Subj. 2019, 1863, 1292-1301. [CrossRef] [PubMed]

25. Kühn, T.; Stepien, M.; López-Nogueroles, M.; Damms-Machado, A.; Sookthai, D.; Johnson, T.; Roca, M.; Hüsing, A.; Maldonado, S.G.; Cross, A.J.; et al. Pre-diagnostic plasma bile acid levels and colon cancer risk: A prospective study. J. Natl. Cancer Inst. 2020, 112, 516-524. [CrossRef] [PubMed]

26. Wan, Y.; Wang, F.; Yuan, J.; Li, J.; Jiang, D.; Zhang, J.; Li, H.; Wang, R.; Tang, J.; Huang, T.; et al. Effects of dietary fat on gut microbiota and faecal metabolites, and their relationship with cardiometabolic risk factors: A 6-month randomised controlled-feeding trial. Gut 2019, 68, 1417-1429. [CrossRef] [PubMed]

27. Ou, J.; Carbonero, F.; Zoetendal, E.G.; DeLany, J.P.; Wang, M.; Newton, K.; Gaskins, H.R.; O'Keefe, S.J.D. Diet, microbiota, and microbial metabolites in colon cancer risk in rural Africans and African Americans. Am. J. Clin. Nutr. 2013, 98, 111-120. [CrossRef] 
28. O'Keefe, S.J.D.; Li, J.V.; Lahti, L.; Ou, J.; Carbonero, F.; Mohammed, K.; Posma, J.M.; Kinross, J.; Wahl, E.; Ruder, E.; et al. Fat, fibre and cancer risk in African Americans and rural Africans. Nat. Commun. 2015, 6, 6342. [CrossRef]

29. Degirolamo, C.; Modica, S.; Palasciano, G.; Moschetta, A. Bile acids and colon cancer: Solving the puzzle with nuclear receptors. Trends Mol. Med. 2011, 17, 564-572. [CrossRef]

30. Pai, R.; Tarnawski, A.S.; Tran, T. Deoxycholic acid activates beta-catenin signaling pathway and increases colon cell cancer growth and invasiveness. Mol. Biol. Cell. 2004, 15, 2156-2163. [CrossRef]

31. Cheng, K.; Raufman, J.P. Bile acid-induced proliferation of a human colon cancer cell line is mediated by transactivation of epidermal growth factor receptors. Biochem. Pharmacol. 2005, 70, 1035-1047. [CrossRef]

32. Amaral, J.D.; Viana, R.J.; Ramalho, R.M.; Steer, C.J.; Rodrigues, C.M.P. Bile acids: Regulation of apoptosis by ursodeoxycholic acid. J. Lipid Res. 2009, 50, 1721-1734. [CrossRef] [PubMed]

33. Maran, R.R.M.; Thomas, A.; Roth, M.; Sheng, Z.; Esterly, N.; Pinson, D.; Gao, X.; Zhang, Y.; Ganapathy, V.; Gonzalez, F.J.; et al. Farnesoid $X$ receptor deficiency in mice leads to increased intestinal epithelial cell proliferation and tumor development. J. Pharmacol. Exp. Ther. 2009, 328, 469-477. [CrossRef] [PubMed]

34. Bailey, A.M.; Zhan, L.; Maru, D.; Shureiqi, I.; Pickering, C.R.; Kiriakova, G.; Izzo, J.; He, N.; Wei, C.; Baladandayuthapani, V.; et al. FXR silencing in human colon cancer by DNA methylation and KRAS signaling. Am. J. Physiol. Gastrointest. Liver Physiol. 2014, 306, G48-G58. [CrossRef] [PubMed]

35. Dermadi, D.; Valo, S.; Ollila, S.; Soliymani, R.; Sipari, N.; Pussila, M.; Sarantaus, L.; Linden, J.; Baumann, M.; Nyström, M. Western diet deregulates bile acid homeostasis, cell proliferation, and tumorigenesis in colon. Cancer Res. 2017, 77, 3352-3363. [CrossRef]

36. Sasso, A.; Latella, G. Dietary components that counteract the increased risk of colorectal cancer related to red meat consumption. Int. J. Food Sci. Nutr. 2018, 69, 536-548. [CrossRef]

37. Hullings, A.G.; Sinha, R.; Liao, L.M.; Freedman, N.D.; Graubard, B.I.; Loftfield, E. Whole grain and dietary fiber intake and risk of colorectal cancer in the NIH-AARP Diet and Health Study cohort. Am. J. Clin. Nutr. 2020, 112, 603-612. [CrossRef]

38. Bakken, T.; Braaten, T.; Olsen, A.; Kyro, C.; Lund, E.; Skeie, G. Consumption of whole-grain bread and risk of colorectal cancer among Norwegian women (the NOWAC Study). Nutrients 2016, 8, 40. [CrossRef]

39. Vulcan, A.; Brändstedt, J.; Manjer, J.; Jirström, K.; Ohlsson, B.; Ericson, U. Fibre intake and incident colorectal cancer depending on fibre source, sex, tumour location and Tumour, Node, Metastasis stage. Br. J. Nutr. 2015, 114, 959-969. [CrossRef]

40. Sansbury, L.B.; Wanke, K.; Albert, P.S.; Kahle, L.; Schatzkin, A.; Lanza, E.; Polyp Prevention Trial Study Group. The Polyp Prevention Trial Study Group. The effect of strict adherence to a high-fiber, high-fruit and -vegetable, and low-fat eating pattern on adenoma recurrence. Am. J. Epidemiol. 2009, 170, 576-584. [CrossRef]

41. Jacobs, E.T.; Giuliano, A.R.; Roe, D.J.; Guillén-Rodríguez, J.M.; Alberts, D.S.; Martínez, M.E. Baseline dietary fiber intake and colorectal adenoma recurrence in the wheat bran fiber randomized trial. J. Natl. Cancer Inst. 2002, 94, 1620-1625. [CrossRef]

42. Young, G.P.; Hu, Y.; Le Leu, R.K.; Nyskohus, L. Dietary fiber and colorectal cancer: A model for environment-gene interactions. Mol. Nutr. Food Res. 2005, 49, 571-584. [CrossRef] [PubMed]

43. Bultman, S.J. The microbiome and its potential as a cancer preventive intervention. Semin. Oncol. 2016, 43, 97-106. [CrossRef] [PubMed]

44. Pye, G.; Evans, D.F.; Ledingham, S.; Hardcastle, J.D. Gastrointestinal intraluminal pH in normal subjects and those with colorectal adenoma or carcinoma. Gut 1990, 31, 1355-1357. [CrossRef] [PubMed]

45. Vernia, P.; Ciarniello, P.; Cittadini, M.; Lorenzotti, A.; Alessandrini, A.; Caprilli, R. Stool pH and SCFA in in colorectal cancer and polyps. Gastroenterology 1989, 96, A528.

46. Frieri, G.; Latella, G.; Vernia, P.; Onori, L.; Caprilli, R. Colonic pH in man. Gastroenetrology 1989, 96, A160.

47. Cummings, J.H.; Pomare, E.W.; Branch, W.J.; Naylor, C.P.; Macfarlane, G.T. Short chain fatty acids in human large intestine, portal, hepatic and venous blood. Gut 1987, 28, 1221-1227. [CrossRef]

48. Latella, G.; Caprilli, R. Metabolism of large bowel mucosa in health and disease. Int. J. Colorectal. Dis. 1991, 6, 127-132. [CrossRef]

49. Zhang, M.; Zhou, Q.; Dorfman, R.G.; Huang, X.; Fan, T.; Zhang, H.; Zhang, J.; Yu, C. Butyrate inhibits interleukin-17 and generates Tregs to ameliorate colorectal colitis in rats. BMC Gastroenterol. 2016, 16, 84. [CrossRef]

50. Zimmerman, M.A.; Singh, N.; Martin, P.M.; Thangaraju, M.; Ganapathy, V.; Waller, J.L.; Shi, H.; Robertson, K.D.; Munn, D.H.; Liu, K. Butyrate suppresses colonic inflammation through HDAC1-dependent Fas upregulation and Fas-mediated apoptosis of T cells. Am. J. Physiol. Gastrointest. Liver Physiol. 2012, 302, G1405-G1415. [CrossRef]

51. Bultman, S.J. Molecular pathways: Gene-environment interactions regulating dietary fiber induction of proliferation and apoptosis via butyrate for cancer prevention. Clin. Cancer Res. 2014, 20, 799-803. [CrossRef]

52. Kolar, S.S.; Barhoumi, R.; Lupton, J.R.; Chapkin, R.S. Docosahexaenoic acid and butyrate synergistically induce colonocyte apoptosis by enhancing mitochondrial Ca2 + accumulation. Cancer Res. 2007, 67, 5561-5568. [CrossRef] [PubMed]

53. Kolar, S.S.; Barhoumi, R.; Callaway, E.S.; Fan, Y.; Wang, N.; Lupton, J.R.; Chapkin, R.S. Synergy between docosahexaenoic acid and butyrate elicits p53-independent apoptosis via mitochondrial $\mathrm{Ca}(2+)$ accumulation in colonocytes. Am. J. Physiol. Gastrointest. Liver Physiol. 2007, 293, G935-G943. [CrossRef] [PubMed]

54. Vernia, P.; Marcheggiano, A.; Caprilli, R.; Frieri, G.; Corrao, G.; Valpiani, D.; Di Paolo, M.C.; Paoluzi, P.; Torsoli, A. Short-chain fatty acid topical treatment in distal ulcerative colitis. Aliment. Pharmacol. Ther. 1995, 9, 309-313. [CrossRef] [PubMed]

55. Velázquez, O.C.; Lederer, H.M.; Rombeau, J.L. Butyrate and the colonocyte. Implications for neoplasia. Dig. Dis. Sci. 1996, 41, 727-739. [CrossRef] 
56. Fauser, J.K.; Prisciandaro, L.D.; Cummins, A.G.; Howarth, G.S. Fatty acids as potential adjunctive colorectal chemotherapeutic agents. Cancer Biol. Ther. 2011, 11, 724-731. [CrossRef]

57. Yuan, C.; Subramanian, S. MicroRNA-mediated tumor-microbiota metabolic interactions in colorectal cancer. DNA Cell Biol. 2019, 38, 281-285. [CrossRef]

58. Patnode, M.L.; Beller, Z.W.; Han, N.D.; Cheng, J.; Peters, S.L.; Terrapon, N.; Henrissat, B.; Le Gall, S.; Saulnier, L.; Hayashi, D.K.; et al. Interspecies competition impacts targeted manipulation of human gut bacteria by fiber derived glycans. Cell 2019, 179, e13. [CrossRef]

59. Uchida, K.; Kono, S.; Yin, G.; Toyomura, K.; Nagano, J.; Mizoue, T.; Mibu, R.; Tanaka, M.; Kakeji, Y.; Maehara, Y.; et al. Dietary fiber, source foods and colorectal cancer risk: The Fukuoka Colorectal Cancer Study. Scand. J. Gastroenterol. 2010, 45, 1223-1231. [CrossRef]

60. Levi, F.; Pasche, C.; Lucchini, F.; La Vecchia, C. Dietary fiber and the risk of colorectal cancer. Eur. J. Cancer 2001, 37, 2091-2096. [CrossRef]

61. Bradbury, K.E.; Appleby, P.N.; Key, T.J. Fruit, vegetable, and fiber intake in relation to cancer risk: Findings from the European Prospective Investigation into Cancer and Nutrition (EPIC). Am. J. Clin. Nutr. 2014, 100, 394S-398S. [CrossRef]

62. Pathi, S.S.; Lei, P.; Sreevalsan, S.; Chadalapaka, G.; Jutooru, I.; Safe, S. Pharmacologic doses of ascorbic acid repress specificity protein (Sp) transcription factors and Sp-regulated genes in colon cancer cells. Nutr. Cancer 2011, 63, 1133-1142. [CrossRef] [PubMed]

63. Donapaty, S.; Louis, S.; Horvath, E.; Kun, J.; Sebti, S.M.; Malafa, M.P. RRR-alpha-tocopherol succinate down-regulates oncogenic Ras signaling. Mol. Cancer Ther. 2006, 5, 309-316. [CrossRef] [PubMed]

64. Dellavalle, C.T.; Xiao, Q.; Yang, G.; Shu, X.O.; Aschebrook-Kilfoy, B.; Zheng, W.; Li, H.L.; Ji, B.T.; Rothman, N.; Chow, W.H.; et al. Dietary nitrate and nitrite intake and risk of colorectal cancer in the Shanghai Women's Health Study. Int. J. Cancer 2014, 134, 2917-2926. [CrossRef] [PubMed]

65. Zhu, Y.; Wang, P.P.; Zhao, J.; Green, R.; Sun, Z.; Roebothan, B.; Squires, J.; Buehler, S.; Dicks, E.; Zhao, J.; et al. Dietary N-nitroso compounds and risk of colorectal cancer: A case-control study in Newfoundland and Labrador and Ontario, Canada. Br. J. Nutr. 2014, 111, 1109-1117. [CrossRef]

66. Vece, M.M.; Agnoli, C.; Grioni, S.; Sieri, S.; Pala, V.; Pellegrini, N.; Frasca, G.; Tumino, R.; Mattiello, A.; Panico, S.; et al. Dietary total antioxidant capacity and colorectal cancer in the Italian EPIC cohort. PLoS ONE 2015, 10, e0142995. [CrossRef]

67. Kalus, W.H.; Filby, W.G. Inhibition of nitrosamine formation by ascorbic acid: Participation of free radicals in its anaerobic reaction with nitrite. Experientia 1980, 36, 147-149. [CrossRef]

68. Wu, K.; Willett, W.C.; Chan, J.M.; Fuchs, C.S.; Colditz, G.A.; Rimm, E.B.; Giovannucci, E.L. A prospective study on supplemental vitamin e intake and risk of colon cancer in women and men. Cancer Epidemiol. Biomarkers Prev. 2002, 11, $1298-1304$.

69. Heine-Bröring, R.C.; Winkels, R.M.; Renkema, J.M.S.; Kragt, L.; van Orten-Luiten, A.C.B.; Tigchelaar, E.F.; Chan, D.S.M.; Norat, T.; Kampman, E. Dietary supplement use and colorectal cancer risk: A systematic review and meta-analyses of prospective cohort studies. Int. J. Cancer 2015, 136, 2388-2401. [CrossRef]

70. Fedirko, V.; Bostick, R.M.; Flanders, W.D.; Long, Q.; Shaukat, A.; Rutherford, R.E.; Daniel, C.R.; Cohen, V.; Dash, C. Effects of vitamin D and calcium supplementation on markers of apoptosis in normal colon mucosa: A randomized, double-blind, placebo-controlled clinical trial. Cancer Prev. Res. 2009, 2, 213-223. [CrossRef]

71. Fedirko, V.; Bostick, R.M.; Flanders, W.D.; Long, Q.; Sidelnikov, E.; Shaukat, A.; Daniel, C.R.; Rutherford, R.E.; Woodard, J.J. Effects of vitamin $\mathrm{D}$ and calcium on proliferation and differentiation in normal colon mucosa: A randomized clinical trial. Cancer Epidemiol. Biomarkers Prev. 2009, 18, 2933-2941. [CrossRef]

72. Gorham, E.D.; Garland, C.F.; Garland, F.C.; Grant, W.B.; Mohr, S.B.; Lipkin, M.; Newmark, H.L.; Giovannucci, E.; Wei, M.; Holick, M.F. Vitamin D and prevention of colorectal cancer. J. Steroid Biochem. Mol. Biol. 2005, 97, 179-194. [CrossRef] [PubMed]

73. Manson, J.E.; Cook, N.R.; Lee, I.M.; Christen, W.; Bassuk, S.S.; Mora, S.; Gibson, H.; Gordon, D.; Copeland, T.; D' Agostino, D.; et al. Vitamin D supplements and prevention of cancer and cardiovascular disease. N. Engl. J. Med. 2019, 380, 33-44. [CrossRef] [PubMed]

74. Maciel-Dominguez, A.; Swan, D.; Ford, D.; Hesketh, J. Selenium alters miRNA profile in an intestinal cell line: Evidence that miR-185 regulates expression of GPX2 and SEPSH2. Mol. Nutr. Food Res. 2013, 57, 2195-2205. [CrossRef] [PubMed]

75. Pais, R.; Dumitrascu, D.L. Do antioxidants prevent colorectal cancer? A meta-analysis. Rom. J. Intern. Med. 2013, 51, 152-163.

76. Thompson, P.A.; Ashbeck, E.L.; Roe, D.J.; Fales, L.; Buckmeier, J.; Wang, F.; Bhattacharyya, A.; Hsu, C.H.; Chow, H.H.S.; Ahnen, D.J.; et al. Selenium supplementation for prevention of colorectal adenomas and risk of associated type 2 diabetes. J. Natl. Cancer Inst. 2016, 108, djw152. [CrossRef]

77. Sobiecki, J.G. Vegetarianism and colorectal cancer risk in a low-selenium environment: Effect modification by selenium status? A possible factor contributing to the null results in British vegetarians. Eur. J. Nutr. 2017, 56, 1819-1832. [CrossRef]

78. Cho, E.; Smith-Warner, S.A.; Spiegelman, D.; Beeson, W.L.; van den Brandt, P.A.; Colditz, G.A.; Folsom, A.R.; Fraser, G.E.; Freudenheim, J.L.; Giovannucci, E.; et al. Dairy foods, calcium, and colorectal cancer: A pooled analysis of 10 cohort studies. J. Natl. Cancer Inst. 2004, 96, 1015-1022. [CrossRef]

79. Baron, J.A.; Barry, E.L.; Mott, L.A. A trial of calcium and vitamin D for the prevention of colorectal adenomas. N. Engl. J. Med. 2015, 373, 1519-1530. [CrossRef] 
80. Cauley, J.A.; Chlebowski, R.T.; Wactawski-Wende, J.; Rees, J.R.; Sandler, R.S.; Snover, D.C.; Bostick, R.M.; Ivanova, A.; Cole, B.F.; Ahnen, D.J.; et al. Calcium plus vitamin D supplementation and health outcomes five years after active intervention ended: The Women's Health Initiative. J. Womens Health 2013, 22, 915-929. [CrossRef]

81. Newmark, H.L.; Wargovich, M.J.; Bruce, W.R. Colon cancer and dietary fat, phosphate, and calcium: A hypothesis. J. Natl. Cancer Inst. 1984, 72, 1323-1325.

82. Sesink, A.L.; Termont, D.S.; Kleibeuker, J.H.; Van der Meer, R. Red meat and colon cancer: Dietary haem-induced colonic cytotoxicity and epithelial hyperproliferation are inhibited by calcium. Carcinogenesis 2001, 22, 1653-1659. [CrossRef] [PubMed]

83. Tu, H.; Flanders, W.D.; Ahearn, T.U.; Daniel, C.R.; Gonzalez-Feliciano, A.G.; Long, Q.; Rutherford, R.E.; Bostick, R.M. Effects of calcium and vitamin D3 on transforming growth factors in rectal mucosa of sporadic colorectal adenoma patients: A randomized controlled trial. Mol. Carcinog. 2015, 54, 270-280. [CrossRef] [PubMed]

84. Yang, K.; Yang, W.; Mariadason, J.; Lipkin, M.; Augenlicht, L. Dietary components modify gene expression: Implications for carcinogenesis. J. Nutr. 2005, 135, 2710-2714. [CrossRef] [PubMed]

85. Singh, N.; Gurav, A.; Sivaprakasam, S.; Brady, E.; Padia, R.; Shi, H.; Thangaraju, M.; Prasad, P.D.; Manicassamy, S.; Munn, D.H.; et al. Activation of Gpr109a, receptor for niacin and the commensal metabolite butyrate, suppresses colonic inflammation and carcinogenesis. Immunity 2014, 40, 128-139. [CrossRef] [PubMed]

86. Rowland, G.; Gibson, A.; Heinken, K.; Scott, K.; Swann, J.; Thiele, I.; Tuohy, K. Gut microbiota functions: Metabolism of nutrients and other food components. Eur. J. Nutr. 2018, 57, 1-24. [CrossRef] [PubMed]

87. Song, M.; Chan, A.T.; Sun, J. Influence of the gut microbiome, diet, and environment on risk of colorectal cancer. Gastroenterology 2020, 158, 322-340. [CrossRef] [PubMed]

88. Han, S.; Zhuang, J.; Wu, Y.; Wu, W.; Yang, X. Progress in research on colorectal cancer-related microorganisms and metabolites. Cancer Manag. Res. 2020, 12, 8703-8720. [CrossRef]

89. Yan, X.L.; Zhang, X.B.; Ao, R.; Guan, L. Effects of shRNA-mediated silencing of PKM2 gene on aerobic glycolysis, cell migration, cell invasion, and apoptosis in colorectal cancer cells. J. Cell Biochem. 2017, 118, 4792-4803. [CrossRef]

90. Graziano, F.; Ruzzo, A.; Giacomini, E.; Ricciardi, T.; Aprile, G.; Loupakis, F.; Lorenzini, P.; Ongaro, E.; Zoratto, F.; Catalano, V.; et al. Glycolysis gene expression analysis and selective metabolic advantage in the clinical progression of colorectal cancer. Pharm. J. 2017, 17, 258-264. [CrossRef]

91. Dutilh, B.E.; Backus, L.; van Hijum, S.A.F.T.; Tjalsma, H. Screening metatranscriptomes for toxin genes as functional drivers of human colorectal cancer. Best Pract. Res. Clin. Gastroenterol. 2013, 27, 85-99. [CrossRef]

92. Ma, C.T.; Luo, H.S.; Gao, F.; Tang, Q.C.; Chen, W. Fusobacterium nucleatum promotes the progression of colorectal cancer by interacting with E-cadherin. Oncol. Lett. 2018, 16, 2606-2612. [CrossRef] [PubMed]

93. Prorok-Hamon, M.; Friswell, M.K.; Alswied, A.; Roberts, C.L.; Song, F.; Flanagan, P.K.; Knight, P.; Codling, C.; Marchesi, J.R.; Winstanley, C.; et al. Colonic mucosa-associated diffusely adherent afaC+ Escherichia coli expressing lpfA and pks are increased in inflammatory bowel disease and colon cancer. Gut 2014, 63, 761-770. [CrossRef] [PubMed]

94. Sze, M.A.; Baxter, N.T.; Ruffin, M.T.; Rogers, M.A.M.; Schloss, P.D. Normalization of the microbiota in patients after treatment for colonic lesions. Microbiome 2017, 5, 150. [CrossRef] [PubMed]

95. Haraguchi, T.; Kayashima, T.; Okazaki, Y.; Inoue, J.; Mineo, S.; Matsubara, K.; Sakaguchi, E.; Yanaka, N.; Kato, N. Cecal succinate elevated by some dietary polyphenols may inhibit colon cancer cell proliferation and angiogenesis. J. Agric. Food Chem. 2014, 62, 5589-5594. [CrossRef] [PubMed]

96. Wu, J.Y.; Huang, T.W.; Hsieh, Y.T.; Wang, Y.F.; Yen, C.C.; Lee, G.L.; Yeh, C.C.; Peng, Y.J.; Kuo, Y.Y.; Wen, H.T.; et al. Cancer-derived succinate promotes macrophage polarization and cancer metastasis via succinate receptor. Mol. Cell. 2020, 77, 213-227. [CrossRef]

97. Vital, M.; Howe, A.C.; Tiedje, J.M. Revealing the bacterial butyrate synthesis pathways by analyzing (meta)genomic data. $m$ Bio 2014, 5, e00889. [CrossRef]

98. Duncan, S.H.; Barcenilla, A.; Stewart, C.S.; Pryde, S.E.; Flint, H.J. Acetate utilization and butyryl coenzyme A (CoA): Acetate-CoA transferase in butyrate-producing bacteria from the human large intestine. Appl. Environ. Microbiol. 2002, 68, 5186-5190. [CrossRef]

99. Fernandes, J.; Wang, A.; Su, W.; Rozenbloom, S.R.; Taibi, A.; Comelli, E.M.; Wolever, T.M.S. Age, dietary fiber, breath methane, and fecal short chain fatty acids are interrelated in Archaea-positive humans. J. Nutr. 2013, 143, 1269-1275. [CrossRef]

100. O'Keefe, S.J. Diet, microorganisms and their metabolites, and colon cancer. Nat. Rev. Gastroenterol. Hepatol. 2016, 13, 691-706. [CrossRef]

101. Slavin, J.L. Dietary fiber and body weight. Nutrition 2005, 21, 411-418. [CrossRef]

102. Sivan, A.; Corrales, L.; Hubert, N.; Williams, J.B.; Aquino-Michaels, K.; Earley, Z.M.; Benyamin, F.W.; Lei, Y.M.; Jabri, B.; Alegreet, M.L.; et al. Commensal Bifidobacterium promotes antitumor immunity and facilitates anti-PD-L1 efficacy. Science 2015, 350, 1084-1089. [CrossRef] [PubMed]

103. Mego, M.; Holec, V.; Drgona, L.; Hainova, K.; Ciernikova, S.; Zajac, V. Probiotic bacteria in cancer patients undergoing chemotherapy and radiation therapy. Complement. Ther. Med. 2013, 21, 712-723. [CrossRef] [PubMed]

104. Gamallat, Y.; Meyiah, A.; Kuugbee, E.D.; Hago, A.M.; Chiwala, G.; Awadasseid, A.; Bamba, D.; Zhang, X.; Shang, X.; Luoet, F.; et al. Lactobacillus rhamnosus induced epithelial cell apoptosis, ameliorates inflammation and prevents colon cancer development in an animal model. Biomed. Pharmacother. 2016, 83, 536-541. [CrossRef] [PubMed] 
105. Kuugbee, E.D.; Shang, X.; Gamallat, Y.; Bamba, D.; Awadasseid, A.; Suliman, M.A.; Zang, S.; Ma, Y.; Chiwala, G.; Xin, Y.; et al. Structural change in microbiota by a probiotic cocktail enhances the gut barrier and reduces cancer via tlr2 signaling in a rat model of colon cancer. Dig. Dis. Sci. 2016, 61, 2908-2920. [CrossRef]

106. Hebels, D.G.; Sveje, K.M.; de Kok, M.C.; van Herwijnen, M.H.M.; Kuhnle, G.G.C.; Engels, J.B.; Vleugels-Simon, C.B.E.M.; Mares, W.G.N.; Pierik, M.; Masclee, A.A.M.; et al. Red meat intake-induced increases in fecal water genotoxicity correlate with pro-carcinogenic gene expression changes in the human colon. Food Chem. Toxicol. 2012, 50, 95-103. [CrossRef]

107. Ota, K.; Dohi, Y.; Brydun, A.; Nakanome, A.; Ito, S.; Igarashi, K. Identification of senescence-associated genes and their networks under oxidative stress by the analysis of Bach1. Antioxid. Redox Signal. 2011, 14, 2441-2451. [CrossRef]

108. Igarashi, K.; Watanabe-Matsui, M. Wearing red for signaling: The heme-bach axis in heme metabolism, oxidative stress response and iron immunology. Tohoku J. Exp. Med. 2014, 232, 229-253. [CrossRef]

109. Li, J.; Shiraki, T.; Igarashi, K. Transcription-independent role of Bach1 in mitosis through a nuclear exporter Crm1- dependent mechanism. FEBS Lett. 2012, 586, 448-454. [CrossRef]

110. Fasanelli, F.; Giraudo, M.T.; Vineis, P.; Fiano, V.; Fiorito, G.; Grasso, C.; Polidoro, S.; Trevisan, M.; Grioni, S.; Krogh, V.; et al. DNA methylation, colon cancer and Mediterranean diet: Results from the EPIC-Italy cohort. Epigenetics 2019, 14, 977-988. [CrossRef]

111. Cho, Y.; Kim, H.; Turner, N.D.; Mann, J.C.; Wei, J.; Taddeo, S.S.; Davidson, L.A.; Wang, N.; Vannucci, M.; Carroll, R.J.; et al. A chemoprotective fish oil- and pectincontaining diet temporally alters gene expression profiles in exfoliated rat colonocytes throughout oncogenesis. J. Nutr. 2011, 141, 1029-1035. [CrossRef]

112. Cho, Y.; Turner, N.D.; Davidson, L.A.; Chapkin, R.S.; Carroll, R.J.; Lupton, J.R. Colon cancer cell apoptosis is induced by combined exposure to the $\mathrm{n}-3$ fatty acid docosahexaenoic acid and butyrate through promoter methylation. Exp. Biol. Med. 2014, 239, 302-310. [CrossRef] [PubMed]

113. Ding, S.; Xu, S.; Fang, J.; Jiang, H. The protective effect of polyphenols for colorectal cancer. Front. Immunol. 2020, $11,1407$. [CrossRef] [PubMed]

114. Chen, J.; Qin, F.; Li, Y.; Mo, S.; Deng, K.; Huang, Y.; Liang, W. High-dose vitamin C tends to kill colorectal cancer with high MALAT1 expression. J. Oncol. 2020, 2020, 2621308. [CrossRef] [PubMed]

115. Boughanem, H.; Hernandez-Alonso, P.; Tinahones, A.; Babio, N.; Salas-Salvadó, J.; Tinahones, F.J.; Macias-Gonzalez, M. Association between serum vitamin B12 and global DNA methylation in colorectal cancer patients. Nutrients 2020, $12,3567$. [CrossRef]

116. Al-Ghafari, A.B.; Balamash, K.S.; Al Doghaither, H.A. Relationship between serum vitamin D and calcium levels and vitamin D receptor gene polymorphisms in colorectal cancer. Biomed. Res. Int. 2019, 2019, 8571541. [CrossRef]

117. Hu, Y.; McIntosh, G.H.; Leu, R.K.L.; Nyskohus, L.S.; Woodman, R.J.; Young, G.P. Combination of selenium and green tea improves the efficacy of chemoprevention in a rat colorectal cancer model by modulating genetic and epigenetic biomarkers. PLoS ONE 2013, 8, e64362. [CrossRef]

118. Béjar, L.M.; Gili, M.; Infantes, B.; Marcott, P.F. Effects of changes in dietary habits on colorectal cancer incidence in twenty countries from four continents during the period 1971-2002. Rev. Esp. Enferm. Dig. 2011, 103, 519-529. [CrossRef] 